\title{
Evaluasi Pelaksanaan Pembelajaran Daring di TK Dari Perspektif Anak Usia Dini
}

\author{
Aan Listiana ${ }^{1}$, Yeni Rachmawati ${ }^{1}$, Nadhira Putri Adriana ${ }^{1}$,Tucy Tritita ${ }^{1}$ \\ Pendidikan Guru Pendidik Anak Usia Dini, Universitas Pendidikan Indonesia(1) \\ DOI: $10.31004 /$ obsesi.v6i4.1969
}

\begin{abstract}
Abstrak
Sebagai dampak adanya wabah Covid 19 maka diterapkan model pembelajaran dari rumah secara daring. Dalam penerapannya banyak ditemukan kendala dan tantangan baik yang dikemukakan oleh orang tua maupun oleh guru di lapangan. Penelitian ini bertujuan untuk memperoleh data tentang pendapat anak terhadap pembelajaran daring yang telah dilakukannya selama ini. Responden dalam penelitian ini adalah 105 anak usia 5-6 tahun di wilayah Bandung. Metode penelitian yang digunakan adalah metode kuantitatif dengan teknik survey sedangkan analisis data menggunakan analisis deskriptif dengan menggunakan prosentase. Hasil penelitian menunjukan bahwa pada umumnya $57,1 \%$ anakanak merasa bosan belajar di rumah dan lebih menyukai belajar di sekolah. Sedangkan sekitar 42,9\% menyatakan senang belajar di rumah. Data tersebut menunjukkan bahwa anak-anak sebagian besar cenderung menyukai kegiatan belajar di sekolah dibandingkan dengan belajar di rumah. Anak-anak merasa bosan dengan kegiatan belajar dari rumah secara daring.
\end{abstract}

Kata kunci: anak usia din;, pandemik covid-19; pembelajaran daring

\begin{abstract}
As a result of the COVID-19 outbreak, an online learning model has been implemented. In its application, many obstacles and challenges were found, both raised by parents and by teachers in the field. This study aims to obtain data about children's opinions on online learning that they have done so far. Respondents in this study were 105 children aged 5-6 years in the Bandung area. The research method used is a quantitative method with survey techniques while data analysis uses descriptive analysis using percentages. The results showed that in general $57.1 \%$ of children felt bored studying at home and preferred to study at school. Meanwhile, around $42.9 \%$ stated that they enjoy studying at home. The data shows that children mostly tend to like learning activities at school compared to studying at home. Children feel bored with online learning activities from home.
\end{abstract}

Keywords: early childhood; covid-19 pandemic; online learning

Copyright (c) 2022 Aan Listiana, et al.

$\triangle$ Corresponding author:

Email Address: aanlistiana@upi.edu (Bandung, Jawa Barat, Indonesia)

Received 18 September 2021, Accepted 4 January 2022, Published 28 January 2022 


\section{PENDAHULUAN}

Di awal tahun 2020 terjadi wabah covid-19 dimana World Health Organization (WHO) pada tanggal 12 Maret 2020 menetapkan covid-19 sebagai pandemik (Zahrotunnimah ,2020). Pandemi covid-19 adalah krisis kesehatan yang dinyatakan dapat menular dari manusia ke manusia melalui percikan batuk/bersin atau melalui kontak fisik (Pragholapati 2020, Rohayani 2020). Kondisi wabah tersebut berdampak pada berbagai sektor kehidupan, termasuk sektor pendidikan dimana pendidikan tidak lagi bisa dilakukan dengan cara tatap muka seperti biasanya. Berdasarkan data dari UNESCO (Surveymeter, 2020) diperoleh data sebanyak 577.305.660 siswa dari mulai jenjang pendidikan Taman Kanak-kanak (TK) sampai menengah atas dan 86.034.287 pelajar dari pendidikan tinggi di seluruh dunia terancam tidak dapat melakukan pembelajaran secara tatap muka. Pemerintah Indonesia sendiri mengeluarkan kebijakan sebagai upaya mengatasi penularan wabah covid-19 yaitu dengan menerapkan pembelajaran dari rumah secara daring mulai dari level pendidikan di Taman Kanak-kanak (TK) sampai Perguruan Tinggi (PT) yang tertuang dalam kebijakan Peraturan Pemerintah Republik Indonesia Nomor 21 Tahun (2020) dan Surat Edaran Kemendikbud Nomor 15 Tahun (2020). Alasan utama penerbitan kebijakan tersebut karena ada anggapan bahwa aktivitas berkumpul dan berinteraksi antara guru dan siswa di sekolah dikhawatirkan dapat menyebabkan virus covid-19 semakin menyebar. Sebagai akibat dari kebijakan tersebut maka stimulasi dan pendampingan pembelajaran yang biasanya diberikan oleh guru di sekolah kini bergeser pada orang tua di rumah (Rohita, 2020). Menyikapi kondisi tersebut membuat para pendidik harus merubah strategi dan metode pengajarannya yang disesuaikan dengan situasi pandemi yaitu melalui pembelajaran melalui on line atau daring.

Model pembelajaran jarak jauh melalui daring yang diterapkan pada semua level pendidikan dalam pelaksanaannya memiliki tantangan dan kendala yang berbeda. Pada jenjang pendidikan tinggi, menengah dan atas penerapan pembelajaran daring tidak memiliki kendala yang berarti. Hal tersebut terjadi kemungkinan dikarenakan mahasiswa atau siswa menengah dan atas sudah terbiasa melakukan pembelajaran daring. Berbeda dengan pendidikan di level rendah khususnya di Taman Kanak-kanak yang ternyata dalam implementasinya tidak mudah. Menurut (Dewi, 2020) sistem pembelajaran daring di Taman Kanak-kanak membuat anak, orang tua dan guru mengalami kesulitan. Sehingga guru, orang tua maupun anak memerlukan penyesuaian dalam pelaksanaannya dikarenakan pembelajaran daring berbeda dengan pembelajaran biasanya yaitu menggunakan media seperti zoom ataupun whatsapp.

Ada satu fenomena yang dikeluhkan oleh guru di lapangan berkaitan dengan pembelajaran daring dengan menggunakan zoom atauoun whastsap yaitu adanya indikasi orang tua yang membantu menyelesaikan pekerjaan sekolah yang seharusnya dikerjakan oleh anak. Fenomena tersebut juga diakui oleh salah satu orang tua yang menyatakan kepada penulis bahwa sering kali membantu anak menyelesaikan tugasnya dikarenakan anak tidak mau mengerjakan. Kondisi tersebut menunjukan bahwa kelemahan pembelajaran daring khususnya pada anak usia dini diantaranya adalah kegiatan belajar yang kurang terkontrol, lemahnya pengetahuan orang tua dalam mendidik anak, serta respon yang belum maksimal dari orang tua terhadap instruksi pembelajaran yang diberikan guru. Fenomena lain dari pembelajaran daring adalah pembelajaran daring tidak memberi kesempatan pada anak untuk berinteraksi dan menjalin pertemanan yang merupakan kemampuan esensial yang harus dimiliki anak (Agustin, dkk. 2020). Hal tersebut menyebabkan kemampuankemampuan lainnya seperti sikap tenggang rasa, peduli, saling menyayangi, menghargai dan menghormati satu sama lain menjadi sulit dikembangkan dengan pembelajaran daring dikarenakan pembelajaran daring kurang memungkinkan anak-anak untuk berinteraksi secara langsung.

Beranjak dari permasalahan tersebut di atas maka dalam penelitiani ini bertujuan untuk mengkaji proses pelaksanaan pembelajaran daring khususnya di Taman Kanak-kanak dari perspektif anak. Melalui kajian ini diharapkan para akademisi ataupun peneliti dapat 
DOI: 10.31004/obsesi.v6i4.1969

memperoleh gambaran tentang bagaimana kondisi dan pendapat anak tentang pembelajaran daring yang selama ini dilakukan. Melalui penelitian ini diharapkan akan dapat dijadikan rujukan atau bahan dalam menyusun pembelajaran yang lebih efektif dan dapat mengembangkan kemampuan anak secara optimal di masa pandemik.

\section{METODOLOGI}

Pendekatan yang digunakan dalam penelitian ini berupa pendekatan kuantitatif. Data dalam penelitian ini berupa angka kemudian dianalisis menggunakan statistik deskriptif hingga diperoleh hasil berupa prosentase tentang pendapat anak terhadap pembelajaran daring di TK selama masa pandemik covid-19 serta alasanya. Penelitian ini merupakan bentuk penelitian kuantitatif dengan menggunakan metode survey dikarenakan tujuan penelitian ini adalah untuk memperoleh sejumlah data yaitu pendapat anak di lapangan. Subjek penelitian adalah 105 anak usia 5-6 tahun yang sedang mengikuti pembelajaran daring di Taman Kanakkanak di Kota Bandung.

Penelitian dilakukan pada bulan April-Juni 2020, dengan mengambil lokasi tempat penelitian di Kota Bandung. Alasan dipilihnya Kota Bandung dikarenakan hampir seluruh TK di Kota Bandung menyelenggarakan pembelajarannya dengan menggunakan daring selama masa pandemik covid-19. Populasi dari penelitian ini adalah anak-anak usia 5-6 Tahun di Kota Bandung yang sedang mengikuti pembelajaran daring di Taman Kanak-kanak. Sedangkan sampel dari penelitian ini sejumlah 105 orang anak dengan teknik pengambilan sampel secara insidental, dimana peneliti mengambil sampel secara sembarang.

Mengingat subjek penelitian ini adalah anak usia 5-6 tahun maka instrument yang dikembangkan dibuat dengan sesederhana mungkin dengan tidak memuat pertanyaan yang panjang dan banyak. Instumen penelitian berupa kuesioner yang berisi 4 (empat) pertanyaan yang berkaitan dengan sikap atau pendapat anak terhadap pembelajaran daring. Pertanyaan tersebut yaitu (1) Bagaimana perasaan anak ketika belajar daring? (2) Apakah anak lebih memilih sekolah tatap muka atau pembelajaran daring? (3) Apa alasannya? (4) selama ini siapa yang membantu belajar daring di rumah?

Teknik pengumpulan data dilakukan dengan cara mewawancarai setiap anak dengan menggunakan kuesioner yang telah disiapkan. Dikarenakan subjek penelitian adalah anak usia dini yang membutuhkan pendekatan dan teknik khusus dalam pengambilan data, maka penelitian ini melibatkan 20 orang mahasiswa sebagai asisten peneliti. Masing-masing asisten peneliti mewawancarai 3-5 anak secara langsung (offline).

Sedangkan analisis data dalam penelitian ini menggunakan teknik prosentase dengan langkah-langkah sebagai berikut: 1) Persiapan, pada tahap ini kegiatan yang dilakukan adalah memeriksa setiap jawaban yang dikumpulkan dari responden dengan mengecek kelengkapan identitas responden, kelengkapan setiap lembar angket, dan kelengkapan jawaban yang diberikan oleh responden, 2) Tabulasi Data, yaitu memasukkan data dari hasil pengumpulan data melalui pengisian yang dilakukan responden, 3) Persentase Data, yaitu melihat perbandingan besar kecilnya antara frekuensi jawaban dalam angket yang telah dihitung dalam setiap jumlah persentasenya. Adapun rumus dalam menghitung persentase sebagaimana disajikan pada rumus 1 . Sedangkan alur penelitian diilustrasikan pada gambar 1.

$$
\mathrm{P}=\frac{f}{N} \times 100 \%
$$

\section{Rumus 1. Presentase angket}

Keterangan: $\mathrm{f}$ adalah Frekuensi yang sedang dicari persentasenya, $\mathrm{N}$ adalah Number of cases, dan $\mathrm{p}$ adalah Angka prosentase 


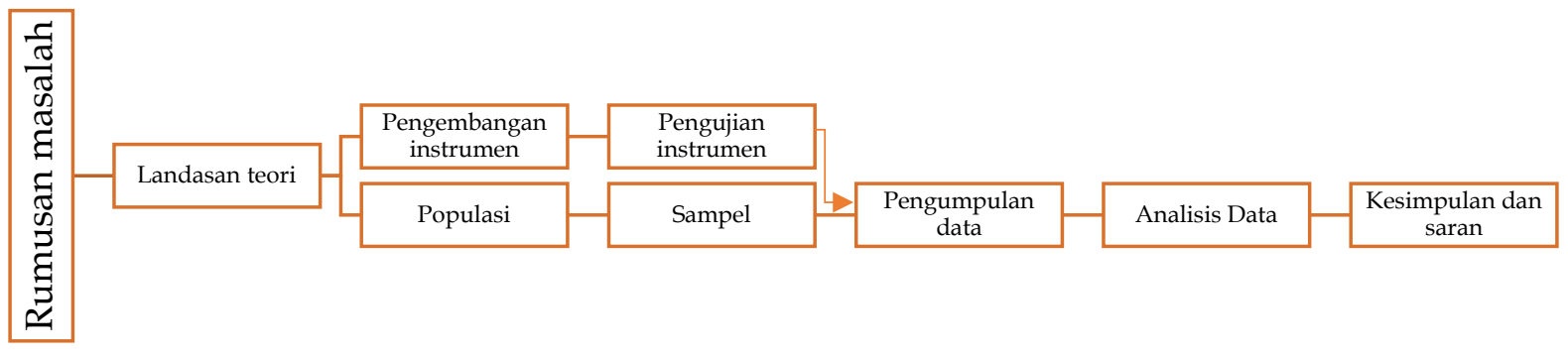

\section{Gambar 1. Alur Penelitian}

\section{HASIL DAN PEMBAHASAN}

Berdasarkan hasil penelitian diperoleh data bahwa umumnya atau sebanyak $57,1 \%$ anak menyatakan lebih senang belajar di sekolah dan sebanyak $42,9 \%$ menyatakan lebih senang belajar di rumah. Alasan anak yang lebih memilih belajar disekolah umumnya dikarenakan banyak teman yaitu $85 \%$ sedangkan alasan lainnya adalah karena bisa bermain, $15 \%$ sisanya menyatakan senang belajar di sekolah karena ada ibu guru. Adapun alasan anak yang memilih senang belajar di rumah (daring), diantaranya $51 \%$ anak menyatakan senang belajar di rumah karena belajarnya bisa sambil bermain, selanjutnya sebanyak $24,4 \%$ menyatakan senang belajar di rumah karena "dibantuin mamah", Ada juga 13,3\% anak yang menyatakan senang belajar di rumah dikarenakan banyak diberi tugas oleh guru, sedangkan sisanya sebanyak $11.1 \%$ senang belajar di rumah karena tidak punya teman di sekolah. Ketika anak ditanya bagaimana perasaannya ketika belajar dirumah sebagian besar yaitu 54,3\% menyatakan bosan dan selebihnya yaitu $45,7 \%$ menyatakan biasa-biasa saja. Sedangkan untuk pendamping anak belajar di rumah, umumnya yaitu $80 \%$ anak menyatakan bahwa selama ini yang mendampingi belajar di rumah adalah ibu, 11,4\% didampingi ayah, 3,8\% kakak dan 4,8\% didampingi kakek atau nenek. Data hasil penelitian tersebut digambarkan dalam bentuk Gambar 2.

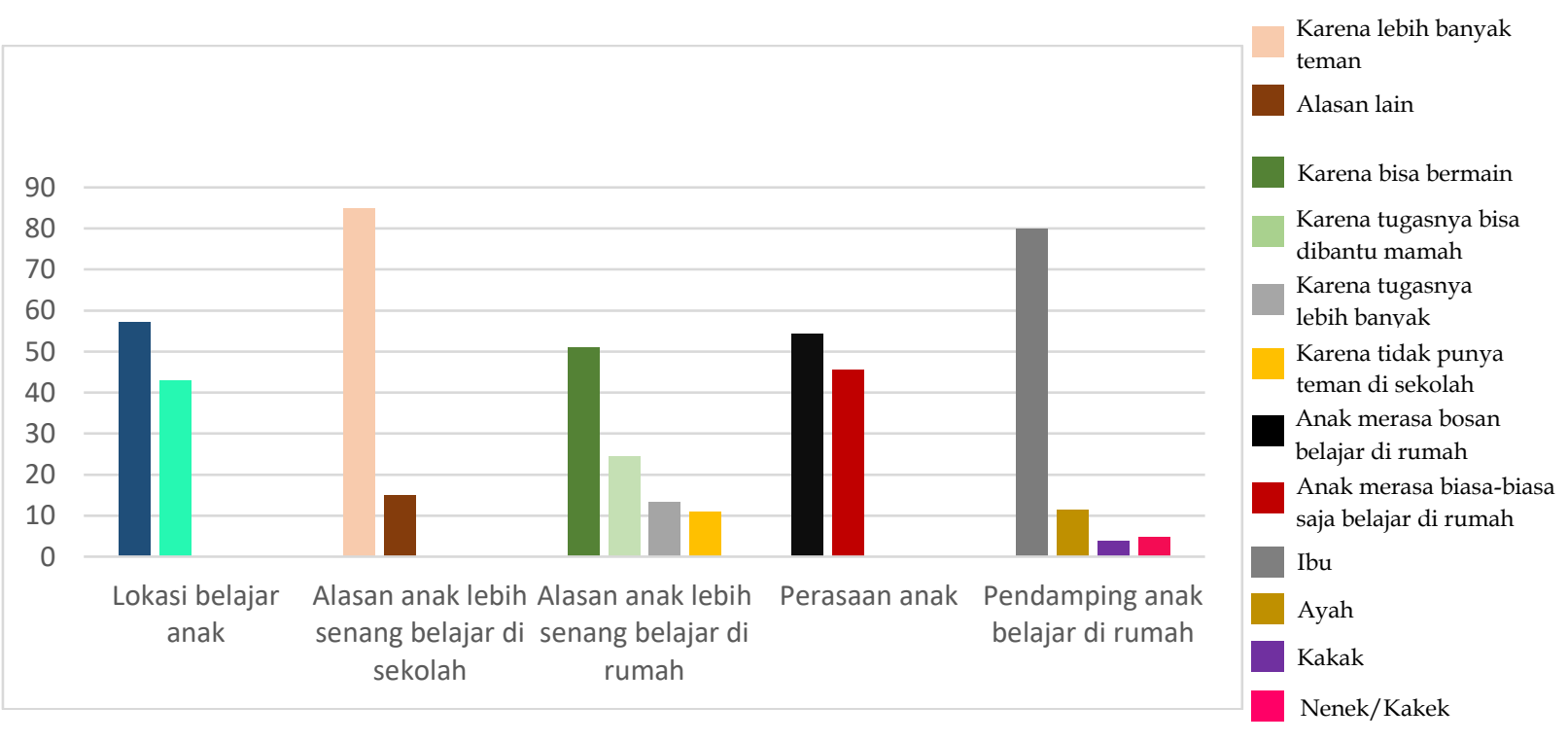

Gambar 2. Preferensi Situasi Belajar Anak

\section{Anak Merasa Bosan dengan Pembelajaran Daring}

Berdasarkan temuan hasil penelitian tersebut terlihat umumnya anak kurang menyukai belajar di rumah secara daring dan umumnya anak-anak juga menyatakan merasa bosan. Hasil penelitian tersebut sejalan dengan yang dikemukakan oleh Trisnawati dan Sugito (2020) bahwa pembelajaran di masa pandemi 19 yang mengharuskan anak belajar dirumah menimbulkan rasa bosan dan stres. Bahkan penelitian yang dilakukan oleh Mei dalam Chandasiri, (2020) bahwa selain merasa stress saat pembelajaran daring anak-anak juga 
menunjukan gejala depresi dan kecemasan. Kondisi tersebut terjadi dikarenakan banyak faktor diantaranya adalah saat pembelajaran daring anak-anak tidak saling berinteraksi dengan teman dan guru juga mengalami kesulitan untuk dapat berkomunikasi dengan anak secara optimal. Selain itu guru juga melaporkan bahwa mereka masih sulit untuk menciptakan situasi pembelajaran yang efektif (Agustin dkk, 2020). Oleh karena itu sangat wajar kalau kemudian anak-anak menjadi jenuh atau bosan dengan pembelajaran daring yang dihadapinya.

Faktor lain yang diduga turut berkontribusi terhadap rasa bosan dan stres pada anak saat pembelajaran daring adalah adanya beban tugas belajar yang banyak dan pembelajaran yang monoton. Menurut Nurdin dan Anhusadar (2020) Selama pandemi ini guru seringnya menitik beratkan kegiatan daring pada pemberian tugas, seperti mengerjakan tugas dari LKS atau meminta anak berkreasi dengan kertas lipat. Pembelajaran yang monoton dan tidak menarik cenderung mendorong anak bersikap sinis dan apatis terhadap pelajaran yang diberikan. Selain itu anak-anak juga menjadi kurang percaya diri dan sulit untuk memahami pelajaran (Arirahman dan Sutam dalam Agusriani dan Fauziddin (2021). Lebih lanjut dikatakan dalam jangka panjang kondisi tersebut hawatir akan membuat anak merasa jenuh dan minat anak untuk belajar menjadi menurun, sehingga akhirnya menyebabkan anak mudah marah, mudah terluka, dan mudah frustasi.

Mengingat kondisi tersebut di atas maka perlu ada upaya untuk dapat menghadirkan kegiatan pembelajaran daring yang variatif dan menantang bagi anak, sehingga anak terhindar dari rasa bosan atau jenuh. Kegiatan pembelajaran yang menghadirkan perangkat digital seperti video, animasi, games interaktif yang berbasis multimedia bisa menjadi alternatif pembelajaran yang digunakan guru agar kegiatan belajar daring jadi lebih menyenangkan. Hal tersebut sesuai dengan yang diungkapkan oleh Koedoes et al. (2020) yang menyatakan bahwa pemilihan media yang menarik seperti video animasi, games interaktif dapat berpengaruh terhadap kegiatan belajar anak, kegiatan belajar akan lebih dinikmati oleh anak dan akan mengurangi kerumitan. Selain itu alternatif lainnya pembelajaran daring yang menyenangkan adalah dengan pemberian tugas belajar yang dapat memberi kesempatan pada anak untuk dapat berinteraksi dengan keluarga seperti bermain bersama anggota keluarga lain seperti melibatkan anak dalam aktivitas bermain bersama (Bluth \& Wahler, 2011; Wulandari dan Purwanta 2020).

\section{Ibu sebagai Pendamping Belajar di Rumah}

Hasil penelitian juga menunjukkan bahwa pendamping belajar daring di rumah umumnya dilakukan oleh ibu dan hanya sedikit saja yang didampingi oleh ayah. Hal tersebut sejalan dengan penelitian oleh Agusriani dan Fauziddin (2021) bahwa ibu merupakan orang yang bertanggung jawab terhadap pendidikan anak di rumah. Lebih lanjut dikatakan bahwa ibu bertanggung jawab lebih besar dibandingkan ayah karena sebagian besar waktu ibu berada di rumah berbeda dengan ayah yang harus bekerja. Ada hal yang cukup menarik terkait dengan respon anak yang menyatakan 57,1\% merasa bosan belajar di rumah, sementara $80 \%$ pendamping anak belajar di rumah adalah ibu. Hal ini dapat mengindikasikan bahwa pendampingan ibu dalam kegiatan belajar di rumah (daring) belum efektif dalam membangun suasana belajar yang menyenangkan.

Menyikapi fenomena tersebut, Nurdin dan Anhusadar (2020) mengungkapkan bahwa salah kemungkinan penyebab orang tua tidak optimal dalam mendampingi anak belajar di rumah, salah satunya dapat disebabkan karena orang tua mengalami stress dan terbebani oleh tugas-tugas sekolah yang diberikan guru. Sehingga ketika ibu mendampingi anak belajar di rumah dilakukan dalam keadaan stress dan marah-marah. Lebih lanjut Nurdin menyatakan bahwa pemberian tugas yang berorientasi produk ini akan menjadi problematika, dimana keterbatasan waktu dan kesabaran orang tua dalam membimbing anak menyebabkan anak mungkin tidak mengerjakan tugas, anak dimarahi orang tuanya atau orang tua mengambil alih pekerjaan anak dan lain sebagainya. Kondisi ibu yang sering memarahi anak saat 
mendampingi belajar tentu saja akan menyebabkan suasana belajar menjadi tidak menyenangkan. Hal senada pun diungkapkan oleh Herlina, Kristiawan, \& Anggraini (2020) yang menyatakan bahwa adakalanya anak terkena imbas dari ketidakmampuan orang tua untuk mendampingi anak selama belajar di rumah, baik dalam hal mengoperasikan gawai atau memahami tugas yang diberikan guru, yang dapat diungkapkan melalui kekerasan secara verbal maupun fisik.

Salah satu solusi untuk mengatasi permasalahan di atas seyogyanya guru menempatkan orang tua sebagai observer bukan sebagai pelaku yang menggantikan posisi guru mengajar. Oleh karena itu pemberian tugas pada anak juga sebaiknya dengan pemberian tugas yang berkaitan dengan aktivitas sehari-hari yang dapat dilakukan anak di rumah, seperti membantu ibu menyapu, menjemur baju, merapihkan tempat tidur, memakai baju sendiri dan membereskan mainan dan lain sebagainya. Sehingga pemberian tugas seperti itu selain melatih kemandirian anak juga akan sangat meringankan tugas orang tua di rumah. Orang tua dapat berperan sebagai asisten guru yang bertugas mengobservasi atau mengamati aktivitas anak dan selanjutnya melaporkan hasil pengamatannya tersebut ke guru pada pertemuan yang telah disepakati. Hal ini tentu akan menjadi solusi baik bagi orang tua maupun guru. Selain itu perlu ada kontrol atau monitoring yang dapat memastikan bahwa anak melakukan tugas sekolahnya sendiri dan bukan dibantu atau dibuatkan oleh orang lain (ibu). Monitoring dapat berupa rekaman video proses anak mengerjakan tugas sekolah ataupun berupa catatan laporan dari orang tua tentang proses anak mengerjakan tugas sekolah. Dengan demikian diharapkan fenomena orang tua membantu menyelesaikan pekerjaan sekolah anak dapat diminimalisir.

Selain itu salah satu alternatif pembelajaran daring lainnya agar orang tua tidak stress adalah dengan menghadirkan orientasi pembelajaran daring yang diarahkan pada aktivitas yang dapat membantu orang tua dan anak untuk berinteraksi dalam suasana yang menyenangkan (Kurniati, Alfaeni, \& Andriani, 2020). Contohnya adalah sepeti meminta anak bermain permainan sederhana seperti petak umpet atau kertas batu gunting dan lain sebagainya. Setelah itu guru juga dapat berinteraksi dengan anak melalui video call untuk meminta anak bercerita tentang aktivitas bermain yang sudah dilakukan bersama orang tuanya. Aktivitas belajar tersebut selain menyenangkan juga dapat mengembangkan aspek sosioal emosional yang selama pembelajaran daring sebelumnya mengalami penurunan signifikan. Hal tersebut sesuai dengan yang diungkapkan oleh hasil penelitian yang dilakukan oleh Wulandari dan Purwanta (2020), bahwa capaian aspek sosial emosional selama pembelajaran daring mengalami penurunan yang paling signifikan diikuti oleh aspek nilai moral dan agama.

\section{SIMPULAN}

Berdasarkan hasil penelitian menunjukan pembelajaran daring dalam pandangan anak belum berjalan efektif, dimana sebagian besar anak merasa bosan. Kemungkinan penyebabnya adalah karena metode pembelajaran daring yang masih berorientasi pemberian tugas yang menghasilkan produk. Alternatif solusinya adalah dengan menciptakan model pembelajaran daring yang interaktif, variatif dan menggunkan media digital seperti video animasi dan games. Selain itu pembelajaran daring juga dapat didesain dengan pembelajaran yang melibatkan anggota keluarga (ayah, ibu atau kakak) dalam penyelesaian tugasnya seperti kegiatan menghias kue, membangun menara dari kubus atau bermain kejar tangkap dan lain sebagainya. Melalui kegiatan pembelajaran tersebut maka diharapkan pembelajaran daring akan jauh lebih menyenangkan.

\section{UCAPAN TERIMA KASIH}

Terima kasih pada Prodi PGPAUD FIP Universitas Pendidikan Indonesia yang telah membiayai proses penelitian ini. Terima kasih juga disampaikan kepada mahasiswa PGPAUD FIP UPI yang membantu mengumpulkan data penelitian. 


\section{DAFTAR PUSTAKA}

Agusriani, Ade, \& Fauziddin, M. (2021). Strategi Orangtua Mengatasi Kejenuhan Anak Belajar Dari Rumah Selama Pandemi Covid-19. Jurnal Obsesi: Jurnal Pendidikan Anak Usia Dini 5(2): 1729-40. https://doi.org/10.31004/obsesi.v5i2.961

Agustin, M., Puspita, R. D., Nurinten, D., \& Nafiqoh, H. (2020). Tipikal Kendala Guru PAUD Dalam Mengajar Pada Masa Pandemi Covid 19 Dan Implikasinya. Jurnal Obsesi: Jurnal Pendidikan Anak Usia Dini 5(1): 334. https:/ / doi.org/10.31004/obsesi.v5i1.598

Bluth, K., \& Wahler, R. G. (2011). Does Effort Matter in Mindful Parenting?. Mindfulness, 2(3), 175-178. https://doi.org/10.1007/s12671-011-0056-3

Chandasiri, O. (2020). The COVID-19: Impact on Education. International Journal of Advanced Education and Research, 5(3), 13-14.

Dewi, P.A. (2020). Karantina Pengaruhi Tumbuh Kembang dan Kemandirian Anak. Diakses melalui https://jakarta.ayoindonesia.com/karantina-pengaruhi-tumbuh-kembangkemandirian-anak/2020/04/30.

Herlina, Y., Kristiawan, M., \& Anggraini, D. (2021). Learning From Home in Early Childhood Education Students. In International Conference on Educational Sciences and Teacher Profession (ICETeP 2020), Advances in Social Sciences, Education, and Humanities Research, 532, 523-531. Atlantis Press. https:// doi.org/10.2991/assehr.k.210227.090

Koedoes, Aryani, Y., Abubakar, S. R., Nadzirin, M., \& Nur, A. (2020). Solusi Pembelajaran Anak Usia Dini Pada Masa Pandemi Covid-19. Jurnal Pengabdian Masyarakat Ilmu Terapan 2(2): 87-92.

Kurniati, E., Alfaeni, D. K. N., \& Andriani, F. (2020). Analisis Peran Orang Tua dalam Mendampingi Anak di Masa Pandemi Covid-19. Jurnal Obsesi: Jurnal Pendidikan Anak Usia Dini, 5(1), 241-256. https://doi.org/10.31004/obsesi.v5i1.541

Nurdin \& Anhusadar, L. (2020). Efektivitas Pembelajaran Online Pendidik PAUD di Tengah Pandemi Covid 19. Jurnal Obsesi: Jurnal Pendidikan Anak Usia Dini 5(1): 686. https://doi.org/10.31004/obsesi.v5i1.699

Peraturan Pemerintah Republik Indonesia Nomor 21 Tahun 2020. PSBB dalam Rangka Percepatan Penanganan COVID-19. Diakses melalui https://covid19.go.id/p/regulasi/.

Pragholapati, A. (2020). Covid-19 Impact on Students, Academia.edu, 1-6. https://doi.org/10.35542/osf.io/895ed

Rohayani, F. (2020). Menjawab Problematika yang Dihadapi Anak Usia Dini di Masa Pandemi Covid-19. Qawwam, 14(1), 29-50. https://doi.org/10.20414/qawwam.v14i1.2310

Rohita. (2020). Pengenalan Covid-19 Pada Anak Usia Prasekolah: Analisis pada Pelaksanaan Peran Orangtua di Rumah. Jurnal Obsesi : Jurnal Pendidikan Anak Usia Dini 5(1): 315. https://doi.org/10.31004/obsesi.v5i1.528

Surat Edaran Kemendikbud Nomor 15 Tahun 2020. Pedoman Penyelenggaraan Belajar dari Rumah. Diakses melalui https://www.kemdikbud.go.id/main/blog/2020/05/.

Surveymeter, (2020). Dampak Covid-19 terhadap Pendidikan Anak. Diakses melalui https://surveymeter.org/id/node/568.

Trisnawati, W., \& Sugito, S. (2020). Pendidikan Anak dalam Keluarga Era Covid-19. Jurnal Obsesi: Jurnal Pendidikan Anak Usia Dini 5(1): 823-31. https://doi.org/10.31004/obsesi.v5i1.710

Wulandari, H., \& Purwanta, E. (2020). Pencapaian Perkembangan Anak Usia Dini di Taman Kanak-Kanak Selama Pembelajaran Daring di Masa Pandemi Covid-19. Jurnal Obsesi: Jurnal Pendidikan Anak Usia Dini 5(1): 452. https:// doi.org/10.31004/obsesi.v5i1.626

Zahrotunnimah. (2020). Langkah Taktis Pemerintah Daerah dalam Pencegahan Penyebaran Virus Corona Covid-19 di Indonesia. SALAM: Jurnal Sosial dan Budaya Syar-i, 7(3): 247-60. https://doi.org/10.15408/sjsbs.v7i3.15103 